\title{
УДК 377:61
}

\section{DIAGNOSTICS OF THE SITUATION OF PROFESSIONAL-PERSONAL IDENTITY OF FUTURE FACTORS OF THE SEASONAL CASE ДІАГНОСТИКА СТАНУ СФОРМОВАНОСТІ ПРОФЕСІЙНО-ОСОБИСТІСНОЇ ІДЕНТИЧНОСТІ МАЙБУТНІХ ФАХІВЦІВ СЕСТРИНСЬКОЇ СПРАВИ}

Prokopchuk V.Y. / Прокопчук В. Ю.

Researcher of the Department of Social Sciences / здобувач кафедри суспільних дисииллін National University of Water Management and Nature Management Національний університет водного господарства та природокористування

У статті розглянуто та охарактеризовано діагностику сформованості професійноособистісної ідентичності майбутніх фахівців сестринської справи у контексті аналізу рівнів сформованості основних компонентів професійно-особистісної ідентичності майбутніх медичних спеціалістів з медичною освітою першого та початку другого року навчання.

Обгрунтовано з допомогою яких відповідних методик проводилася оцінки стану сформованості професійно-особистісної ідентичності майбутніх фахівиів сестринської справи на констатувальному етапі педагогічного експерименту. Відстежено засвоєння студентами медичного коледжу вмінь професійно-особистісної самодіагностики крізь призму формування навиків самоспостереження, самоаналізу, рефлексії, самопізнання.

Ключові слова: констатувальний етап, діагностика, стан сформованості, методики, професійно-особистісна ідентичність, майбутні фахівиі сестринської справи, медичний коледж.

Постановка проблеми. Студентський період життя постає одним 3 найвагоміших у становленні професійно-особистісної ідентичності, адже іï формування є динамічним процесом адаптації особистості до швидкозмінних соціальних умов. Натомість зростання загальних тенденцій негативної самореалізації, що супроводжується напругою або відмовою від позитивного самовизначення особистісного вибору молоді в умовах життєвих труднощів та в ситуаціях трансформаційних зрушень звичної системи цінностей, мотивів під час навчання в медичних навчальних закладах, що обумовлює нагальну потребу формування професійно-особистісної ідентичності.

Саме тому здійснений теоретичний аналіз проблеми формування професійно-особистісної ідентичності майбутніх фахівців сестринської справи 3 метою виявлення стану їі сформованості, особливостей досягнення позитивної й запобігання кризових та дифузних станів потребує проведення експериментального дослідження. А тому практична перевірка ефективності реалізації організаційно-педагогічних умов та моделі формування професійноособистісної ідентичності майбутніх фахівців сестринської справи у процесі навчання в медичному коледжі задає необхідність висвітлення кола питань щодо організації та методики експериментально-дослідної роботи й узагальнення iї результатів. У зв'язку з цим третій розділ наукової розвідки зосереджено на розкритті особливостей основних етапів педагогічного дослідження та аналізу результатів констатувального, формувального i узагальнюючого експериментів упродовж 2015-2019 років.

У цьому контексті на першому етапі (констатувальний), який відбувався 
протягом 2015-2016 p.p. проводилася діагностика сформованості особистісної ідентичності студентів медичних коледжів першого та початку другого року навчання для визначення основних показників, які розкривають рівні сформованості професійно-особистісної ідентичності майбутніх фахівців сестринської справи та експлікації основних способів їх діагностування.

Мета статті - визначення рівня сформованості професійно-особистісної ідентичності майбутніх фахівців сестринської справи на основі проведеного анкетування, реалізованих психологічних методик та тренінгів, результатів аналізу розв'язку проблемних і ситуаційних завдань, завдань практичного спрямування тощо.

Згідно з поставленою метою вирішувались наступні завдання:

- здійснити діагностику сформованості професійно-особистісної ідентичності майбутніх фахівців сестринської справи у контексті аналізу рівнів сформованості основних компонентів професійно-особистісної ідентичності майбутніх медичних спеціалістів 3 медичною освітою;

- визначити критерії та показники, які характеризують окреслені рівні;

- пошук відповідних методик для їх діагностування;

- сприяти засвоєння студентами медичного коледжу вмінь професійноособистісної самодіагностики крізь призму формування навиків самоспостереження, самоаналізу, рефлексії, самопізнання.

Варто зауважити, що діагностика проводилась на практичних заняттях 3 дисциплін «Основи загальної і медичної психології», «Основи психології та міжособове спілкування», «Основи медсестринства», «Догляд за хворими та медична маніпуляцій на техніка».

Виклад основного матеріалу. Констатувальний етап експерименту розпочинався 3 оцінки стану сформованості професійно-особистісної ідентичності майбутніх фахівців сестринської справи за допомогою розробленої авторської анкети «Особистісна ідентичність». До опитування залучалося 338 респондентів.

Шляхом аналізу відповідей на запропоновані запитання анкети ми спостерігаємо, що для більшості студентів поняття ідентичності є незнайомим та незрозумілим. Адже 74 \% опитаних не змогли відповісти на питання «Що Ви вкладаєте в сутнісний зміст поняття «особистісна ідентичність»? та «Як Ви розумієте поняття «особистісна ідентичність студента медичного коледжу?» До 10,37 \% відповідей ми віднесли ті, які за сутнісними характеристиками наближалися до правильного розуміння цього феномена, зокрема: бути самим собою, бути унікальним та неповторним, здатність до самоусвідомлення та самооцінка, ідентифікація із самим собою, пошук себе тощо. Водночас 12,98 \% реципієнтів особистісну ідентичність ідентифікують 3 хорошим здоров'ям, матеріальними достатками, професійністю, релігійністю, авторитетністю, гарним відпочинком та ін. Тоді як 2,65 \% зовсім не цікавляться означеною проблемою. Як бачимо, серед окреслених тлумачень немає чіткого розуміння цієї складної соціально-психологічної характеристики особистості та необхідного розмежування між поняттями «ідентифікація» та «ідентичність» як процесу та результату. 
У зв’язку з цим не є дивним, що на запитання «Чи замислювались Ви над проблемою особистісної ідентичності? Тільки 2,16 \% відповіли позитивно та 5\% - «інколи». Втім, викликає значне занепокоєння те, що, 32 \% респондентів стверджують, що їхнє життя супроводжує тривога та невпевненість в собі, для $19 \%$ - адаптація до студентського життя супроводжувалась негативними емоціями та почуттями, близько 48 \% - невпевнені у своїх можливостях, здібностях, уміннях, 56 \% - бояться публічних виступів.

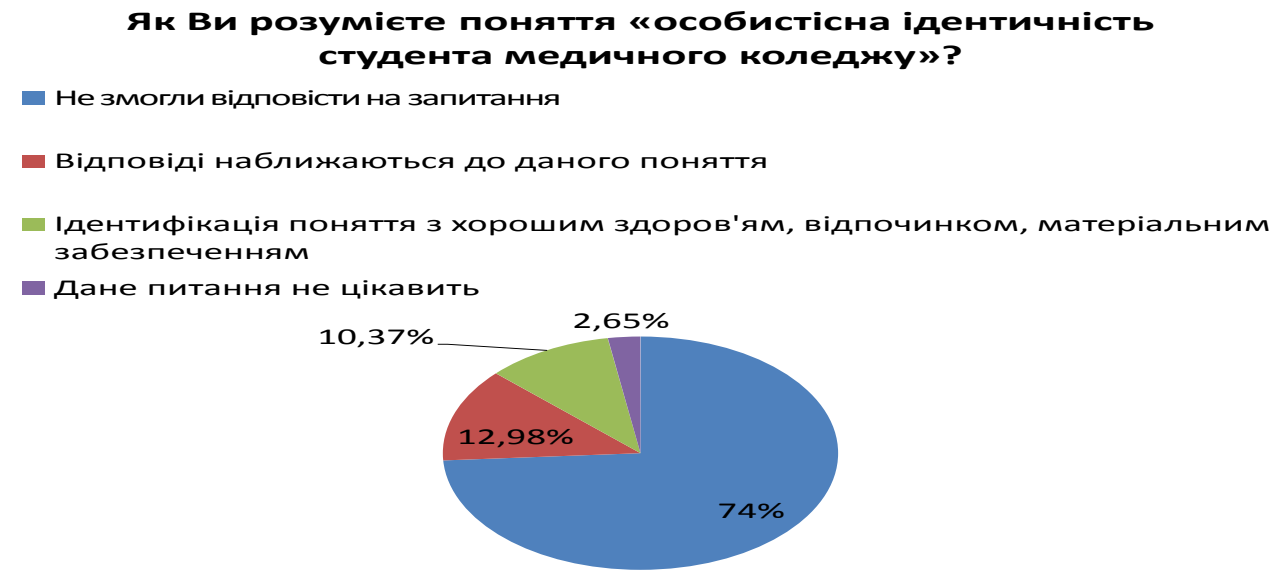

\section{Рис.1. Результати узагальнених даних анкети «Формування професійно- особистісної ідентичності майбутніх фахівців сестринської справи»}

Втім, позитивним, на нашу думку, є те, що 92 \% студентів вважають, що людина повинна прагнути до досягнення стійких ціннісних, моральних та смисложиттєвих орієнтирів і близько 97 \% ствердно відповіли на запитання «Чи хотіли б Ви досягнути особистісного стану, що передбачає цілісність особистості 3 можливостями постійного розвитку, самовизначення, усвідомлення своєї унікальності, смисложиттєвості та оптимізму?» Водночас проведене творче опитування на розуміння особистісної ідентичності в запропонованому творі-есе «Професійно-особистісна ідентичність та їі роль в житті людини» також засвідчило недостатність усвідомлення цього феномена для студентів. Натомість сім робіт нами виокремлено як такі, що певною мірою демонструють адекватне осмислення проблеми професійно-особистісної ідентичності та необхідності іiі формування для майбутніх фахівців медичних коледжів.

Результати проведеного анкетування та творчого есе для діагностики стану сформованості рофесійно-особистісної ідентичності майбутніх фахівців сестринської справи показали, що новий освітній простір змінює рольовий статус, наповнюючи Я-концепцію новими змістовими компонентами, рольовими образами, відмінними від попередньої поведінки тощо. У цьому контексті С.Русина зосереджує увагу на проблемі експлікації кризи ідентичності студентів у період навчання у навчальних закладах у контексті таких аспектів як: особистісна (зміна самооцінки, цінностей, емоційномотиваційної сфери), соціальна (складність міжособистісного спілкування, нестабільність соціальних контактів) та діяльнісна (зміна визначальних аспектів 
діяльності студентів) сфер [12, с.45-46].

Як бачимо, аналіз проведеної нами діагностики продемонстрував недостатність рівнів сформованості професійно-особистісної ідентичності як на спеціальності 5.12010102 «Сестринська справа», так і на спеціальності 5.12010101 «Лікувальна справа». Тобто здобута особистісна ідентичність, яка виражає цілісність власного «Я» і постає необхідною умовою професійноособистісного становлення та успішної професійної самореалізації, проявляється дуже слабко. А тому результати проведеного нами анкетування та аналізу творчих есе спонукає до необхідності осмислення факторів, які сприятимуть визначенню та дослідженню шляхів формування стабільної професійно-особистісної ідентичності майбутніх фахівців сестринської справи.

Нами запропоновано розглядати професійно-особистісну ідентичність майбутніх фахівців сестринської справи як складне динамічне утворення у контексті визначених нами професійно-термінологічного, ціннісноорієнтаційного, емоційно-почуттєвого, комунікативного та діяльнісномотиваційного компонентів. Водночас обгрунтовано доцільність використання відповідних критеріїв, а саме: когнітивно-верифікаційного, гуманістичного, емпатійного, соціально-перцептивного та процесуально-операційного. 3 метою оцінювання рівнів сформованості професійно-особистісної ідентичності за окресленими критеріями нами використовувалися тестові завдання контролю знань, тести-опитувальники, аналіз робіт творчого характеру, завдання проблемного характеру, ситуаційно-творчі завдання, практичні завдання перевірки початкового рівня знань, спостереження, анкетування, діагностувальні методики тощо. 3 метою аналізу отриманих результатів опитування використано метод середніх арифметичних значень (вибіркових середнє - ВС $(\bar{x}))$, що дозволить оцінити досліджувану сукупність одним числом.

Отже, узагальнені результати початкової діагностики сформованості професійно-особистісної ідентичності студентів медичних коледжів у контексті визначених компонентів на етапі констатувального експерименту відображено в таблиці 1.

Таблиця 1.

Узагальнені результати початкової діагностики сформованості особистісної ідентичності студентів медичних коледжів констатувального етапу експерименту

\begin{tabular}{|c|c|c|c|c|c|c|c|c|c|}
\hline \multirow{3}{*}{$\begin{array}{l}\text { Компоненти } \\
\text { сформованості } \\
\text { професійно-особистісної } \\
\text { ідентичності }\end{array}$} & \multicolumn{8}{|c|}{ Рівні } & \multirow{3}{*}{$\mathrm{C \Pi}$} \\
\hline & \multicolumn{2}{|c|}{ Високий } & \multicolumn{2}{|c|}{ Середній } & \multicolumn{2}{|c|}{ Низький } & \multicolumn{2}{|c|}{ Дуже низький } & \\
\hline & $\overline{\mathrm{KC}}$ & $\%$ & КС & $\%$ & $\overline{\mathrm{KC}}$ & $\%$ & $\mathrm{KC}$ & $\%$ & \\
\hline $\begin{array}{l}\text { Професійно- } \\
\text { термінологічний }\end{array}$ & 18 & 5,33 & 134 & 39,65 & 175 & 51,78 & 11 & 3,25 & 3,5 \\
\hline Ціннісно-орієнтаційний & 26 & 7,69 & 172 & 50,89 & 131 & 38,76 & 9 & 2,66 & 3,6 \\
\hline Емоційно-почуттєвий & 23 & 6,80 & 139 & 41,12 & 168 & 49,70 & 8 & 2,37 & 3,5 \\
\hline Комунікативний & 20 & 5,92 & 136 & 40,24 & 176 & 52,05 & 6 & 1,78 & 3,5 \\
\hline $\begin{array}{l}\text { Діяльнісно- } \\
\text { мотиваційний }\end{array}$ & 24 & 7,10 & 129 & 38,17 & 178 & 52,81 & 7 & 1,97 & 3,5 \\
\hline $\begin{array}{l}\text { Узагальнення } \\
\text { показників }\end{array}$ & 22 & 6,51 & 142 & 42,01 & 166 & 49,11 & 8 & 2,37 & 3,5 \\
\hline
\end{tabular}


Властиво, що становлення професійно-особистісної ідентичності зумовлює потребу досягнення високого рівня професіоналізму, тематизуючи вагомість не тільки успішного здійснення операційного зрізу діяльності, але й низки внутрішніх факторів, а саме: «змістовних» (інтерес до професії, необхідність в самореалізації)», «адаптивних» (престижність професії, задоволеність заробітною платою), «дистантності» (усвідомлення про місце професії в інформаційному, полікультурному професійному полі) та ін. [4, с. 63].

Тобто професійне становлення особистості виступає складним процесом формування професійної ідентичності, а відповідно і особистісної як базового підгрунття ідентичності в цілому.

У цій площині значний інтерес для нашого дослідження являє рівень сформованості професійно-особистісної ідентичності за професійнотермінологічною компонентою у зрізі таких показників як: мотивація професійного вибору; рівень засвоєння фахових знань; знання та вільне оперування фаховою термінологією. Зокрема, мотивація професійного вибору визначається нами завдяки опитування щодо мотиваційних та спонукальних засад навчання в медичному коледжі й запропонованих творчих есе «Моя майбутня професія».

Так, у контексті проблемних запитань опитувальника «Професійного вибору студента медичного коледжу» студентам задавались запитання «Яка мета Вашого вступу в медичний коледж?», «Чи Вами зроблено правильний вибір медичної спеціальності?», «Чим плануєте зайнятись після закінчення медичного коледжу?», «Що ускладнює навчання за обраною спеціальністю?» 3 врахуванням того, що студенти вступали в коледж на базі 9 класів, то їх вибір професії $є$ менш усвідомленим. Адже усвідомлений вибір на основі власної мотивації виступає низьким, позаяк основними мотивами вступу в них поставали: поради знайомих, близькість до місця проживання, порада батьків, тощо. Саме тому на цих респондентів випадає більший відсоток на відповідь запитання щодо правильного вибору професії, а саме 38,00 \% відповіло «Не знаю» та $2,42 \%$ - «вступати в інший навчальний заклад». 3 інтересом на заняття відвідують 34,65 \%, по необхідності - 55,97 \%, з бажання найшвидшого закінчення $-9,38 \%$.

Як показали результати аналізу, значна кількість респондентів не впевнена у своєму професійному виборі, це означає, що навчання в коледжі має низку суперечностей, які варто врахувати при реалізації організаційно-педагогічних умов на формувальному етапі.

Водночас студентам пропонувалася тематика творчого есе «Моя майбутня професія».

Властиво, що успішна адаптація студентів в освітній простір коледжу, що впливає на формування професійно-особистісної ідентичності значною мірою залежить від становлення професійної мови майбутніх фахівців, розвиваючи їх термінологічну компетентність. Вимога підвищення рівня знань та якісне професійне оволодіння медичним фахом обумовлена потребою швидкого реагування на ситуацію та прийняття рішення щодо прийняття всіх заходів для спасіння і життя людини і готовністю взяти на себе відповідальність. Саме 
окреслена специфіка професійної діяльності потребує розвинутого аналітичного мислення та хорошої пам'яті, грунтовних фахових знань та оволодіння медичною термінологією, усвідомлене використання якої, сприяє успішному оволодінню обраною спеціальністю. У зв'язку 3 цим ми використовували комплексні завдання початкового оцінювання знань та вільного оперування фаховою термінологією 3 дисциплін «Основи медсестринства», «Догляд за хворими та медична маніпуляційна техніка». Саме розроблені комплексні завдання уможливили виявленню рівнів сформованості професійно-термінологічного компонента професійно-особистісної ідентичності майбутніх фахівців сестринської справи за когнітивним критерієм.

Рівень засвоєння фахових знань діагностувався на основі розробленого автором комплексу завдань для контролю початкового рівня знань, що включав теоретичні запитання, ситуаційні та тестові завдання.

Здійснення тестування, анкетування, розв'язання проблемних завдань професійного характеру, опитування, аналіз творчих робіт дали можливість діагностувати сформованість професійно-термінологічного компонента професійно-особистісної ідентичності майбутніх фахівців сестринської справи. Результати окреслених засобів діагностики засвідчили, що на констатувальному етапі експерименту:

- високий рівень сформованості професійно-термінологічного компонента виявлено у 18 студентів 5,33 \%;

- середній рівень встановлено у 134 студентів (39,65 \%);

- низький рівень (задовільний) властивий 175 студентам $(51,78$ \%);

- дуже низький 11 студентів 3,25 \%.

Значне місце у формуванні професійно-особистісної ідентичності займають ціннісно-орієнтаційні виміри буття людини у світі. Зокрема, Н. Антонова феномен ідентичності редукує до цілісної системи «переконань, цінностей, життєвих цілей людини, які переживаються суб'єктиво як відчуття тотожності і постійності своєї особистості при сприйнятті іншими, які визнають цю тотожність» [2].

Відтак ціннісно-орієнтаційний компонент професійно-особистісної ідентичності майбутніх фахівців сестринської справи за гуманістичним критерієм визначатимемо 3 допомогою таких показників: усвідомлення ціннісної значущості медичного фаху та професійного покликання; засвоєння духовних цінностей, що впливають на ситуацію морального вибору; сформованості системи моральних переконань та стійких форм моральної поведінки; дотримання постулатів та вимог медичної етики й усвідомлення моральної відповідальності за власні дії. Для визначення окреслених показників нами застосовується методика вивчення факторів привабливості професії В. Ядова в модифікації Н. Кузьміної (усвідомлення значущості медичного фаху та професійного покликання) [11, с.97-99], методика М. Рокича [1, с.20]. «Ціннісні орієнтації» (засвоєння духовних цінностей, що впливають на ситуацію морального вибору, сформованості системи моральних переконань та стійких форм моральної поведінки) та анкетування «Базові цінності в структурі моральнісно-професійних цінностей майбутнього медичного працівника» 
(дотримання постулатів та вимог медичної етики, усвідомлення моральної відповідальності за власні діï).

Визначення ролі духовних цінностей студентів було застосовано методику М. Рокича «Ціннісні орієнтири» [3, с. 136]. На основі формування індивідуальних рангів в контексті надання студентами переваги термінальним та інструментальним цінностям визначалися особливості їх ціннісних орієнтацій На рис. 2. відображено рейтинг термінальних цінностей студентів медичних коледжів.

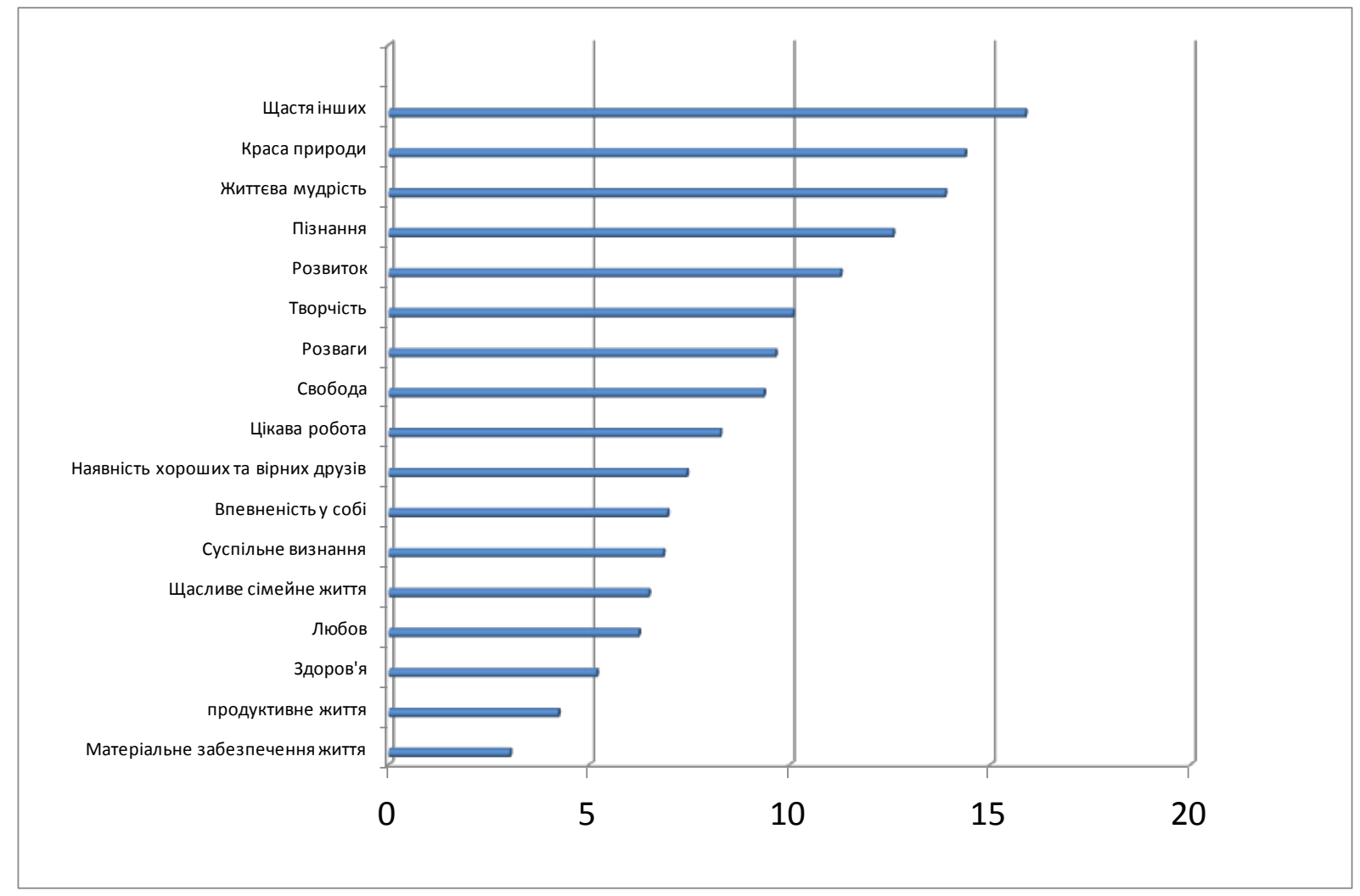

\section{Рис. 2. Рейтинг термінальних цінностей майбутніх фахівців сестринської справи}

На основі формування індивідуальних рангів в контексті надання студентами переваги термінальним та інструментальним цінностям визначалися особливості їх ціннісних орієнтацій.

Зокрема, результати аналізу показали перевагу в ціннісній свідомості студентів таких термінальних цінностей як матеріальне забезпечення життя, задоволення, любов, здоров'я. Меншої значимості набувають такі цінності як пізнання, краса природи, щастя інших людей. Використовуючи інтерпретацію запропонованої методики Д. Леонтьєва [9, с. 22-24], обгрунтовано кореляцію конкретних та абстрактних цінностей.

Так, перевага конкретних цінностей (матеріальне забезпечення життя, задоволення, продуктивне життя, щасливе сімейне життя) над абстрактними (пізнання, творчість, розвиток, щастя інших, краса природи) свідчать про недостатній рівень формування системи цінностей особистості, позаяк саме абстрактні цінності лежать в основі особистісного розвитку. 
Сформованість ціннісно-орієнтаційного компонента професійноособистісної ідентичності майбутніх фахівців сестринської справи за показником «дотримання постулатів та вимог медичної етики, усвідомлення моральної відповідальності за власні дії» здійснюється за допомогою анкети Т. Карнаухової «Моральнісно-професійні цінності у майбутнього медичного працівника у процесі навчання в коледжі» [8, с. 201].

Результати окреслених засобів діагностики засвідчили, що на констатувальному етапі експерименту:

- високий рівень сформованості особистісної ідентичності ціннісноорієнтаційного компонента виявлено у 26 студентів 7,69 \%;

- середній рівень встановлено у 172 студентів (50,89\%);

- низький рівень (задовільний) властивий 131 студентам (38,76 \%);

- дуже низький 9 студентів 2,66 \%.

Отримані результати говорять про недостатній рівень формування системи цінностей майбутніх фахівців сестринської справи, спонукаючи до пошуку ефективних шляхів ¥іi формування. Адже становлення ідентичності супроводжуються постійними життєвими випробуваннями, що призводять до криз особистісного розвитку, протистояти яким здатна розвинута індивідуальність, «наділена системою індивідуально вироблених смислів і відношень до себе і до соціальної реальності в цілому» [3, с. 96].

Дослідження емоційно-почуттєвого компонента професійно-особистісної ідентичності майбутніх фахівців сестринської справи за емпатійним критерієм пропонувалось здійснювати за такими показниками, як: уміння проникати у внутрішній світ іншої людини; вміння керувати емоційно-почуттєвими станами 3 метою запобігання стресових ситуацій; оволодіння навичками самоконтролю та самоаналізу. У цьому контексті нами проводилось визначення вище означеного компонента 3 допомогою методики І. Юсупова «Діагностика рівня емпатії» [10], опитувальника «Емпатія» А. Меграбяна [7, с. 110-113] та Інтегральна самооцінка особистості «Хто Я є в цьому світі» [14, с. 37-38].

Рівень сформованості емоційно-почуттєвого компонента професійноособистісної ідентичності майбутніх фахівців сестринської справи $\epsilon$ недостатнім. Варто врахувати знаходження медичних працівників в негативноемоційному просторі болю, страждань людини та відчаю, постійному перебуванні у стані відповідальності за здоров'я пацієнтів та їх життя. Саме це і дає підстави для необхідності підвищення рівня сформованості емоційнопочуттєвого компонента професійно-особистісної ідентичності майбутніх фахівців сестринської справи за емпатійним критерієм у формувальному етапі педагогічного експерименту.

Для дослідження комунікативного компонента професійно-особистісної ідентичності майбутніх фахівців сестринської справи за соціальноперцептивним критерієм нами використовувалися методи анкетування та тестування, а саме: «Тест на визначення рівня комунікації», розроблений В. Ряховським [13], тест «Тест на виявлення рівня комунікативної культури», запропонований С. Знаменською [6] та тест у авторській модифікації «Чи ефективно Ви спілкуєтесь?». 
Зважаємо на те, що значна роль в питаннях формування професійноособистісної ідентичності залежить від особливостей умов включення суб'єкта в соціальну групу та особливостей їх комунікативної взаємодії. Звичайно, соціальне середовище внормовує i впорядковує професійно-особистісну ідентичність та водночас індивід формує власний особистісний простір, вибираючи відповідну систему цінностей, цілей та потреб.

В цілому, використовуючи запропоновані нами методики, ми побачили, що 5,92 \% (20 студентів) має високий рівень, 40,24 \% (136 студентів) - середній рівень, 52,05\% (176 студенти) - низький рівень, 1,78 \% (6 студентів) - дуже низький рівень сформованості комунікативного компонента професійноособистісної ідентичності майбутніх фахівців сестринської справи за соціальноперцептивним критерієм.

Результати проведеного нами педагогічного експерименту на констатувальному етапі показали недостатність сформованості комунікативного компонента професійно-особистісної ідентичності майбутніх фахівців сестринської справи за соціально-перцептивним критерієм. Реалізовані нами методики засвідчили те, що розвиток ідентичності індивіда має безпосереднє відношення до проблем становлення індивідуальності людини, усвідомлення себе частиною соціуму та водночас розуміння особистісної індивідуальності та неповторності. Втім, абсолютно неможливим є досягнення свого унікального «Я» поза комунікацією, взаємодією з соціальними групами тощо. А тому окреслена цілісність досягається в результаті як індивідуалізації, так і соціалізації, міжособистісного взаєморозуміння та культури спілкування. Саме тому на формувальному етапі експерименту виникає потреба щодо реалізації форм, методів та засобів навчання, які сприятимуть реальному втіленню організаційно-педагогічних умов для формування комунікативної компоненти професійно-особистісної ідентичності майбутніх фахівців сестринської справи у навчально-виховний процес.

Дослідження діяльнісного компонента

професійно-особистісної ідентичності майбутніх фахівців сестринської справи за процесуальноопераційним критерієм пропонувалося здійснювати за такими показниками, як: сформованість професійних знань та умінь; творче вирішення професійних завдань; здатність ідентифікувати, імітувати та копіювати навички виконання певних дій, координувати i модифікувати технічні прийоми, комбінування навичок для виконання типових та нетипових професійних завдань. У зв'язку 3 цим окреслені показники визначалися нами шляхом аналізу результатів тестової діагностики комплексу ситуаційних тестових завдань практичного спрямування; результатів ситуаційно-творчих завдань та практичних завдань перевірки початкового рівня знань.

Шляхом проведеного діагностування крізь призму перевірки наданих для студентів завдань практичного спрямування ми отримали наступні результати. Тільки 7,10 \%, а це 24 студента мають високий рівень сформованості діяльнісного компонента професійно-особистісної ідентичності. Середній рівень показали 38,17 \% (129 студентів), низький 38,17 \% (178 студентів) та дуже низький $-1,97$ \% (7 студентів). 
А відтак, здобута професійно-особистісна ідентичність за процесуальноопераційним критерієм як необхідна умова особистісного становлення та успішної професійної самореалізації в комунікативному просторі проявляється дуже слабко, спонукаючи досліджувати фактори, які сприятимуть формуванню стабільної професійно-особистісної ідентичності майбутніх фахівців сестринської справи.

\section{Висновки.}

Проведений нами аналіз свідчить про наявність суперечностей в навчальному процесі медичного коледжу, а саме суперечність між досвідом шкільного навчання та новими вимогами навчання в медичних навчальних закладах I-II рівнів акредитації; невідповідністю особистісних самооцінки тим вимогам, які ставляться перед ними у навчально-професійному процесі.

Саме тому наступним етапом нашої наукової розвідки постає організація формувального етапу експериментального дослідження 3 метою експериментальної перевірки ефективності реалізації організаційнопедагогічних умов та структурно-функціональної моделі формування професійно-особистісної ідентичності майбутніх фахівців сестринської справи на заняттях 3 дисциплін «Основи загальної і медичної психології», «Основи психології та міжособове спілкування», «Основи медсестринства», «Догляд за хворими та медична маніпуляційна техніка».

\section{Література:}

1. Антонова Н. В. Особенности идентичности преподавателя как фактор успешности обучения практических психологов / Н. В. Антонова // Проблемы педагогической психологии и психологии образования. - МПГУ, 2009. - С. 6072.

2. Антонова Н. В. Проблема личностной идентичности в интерпретации современного психоанализа, интеракционизма и когнитивной психологии / Н. В. Антонова // Вопросы психологии. - 1996. - №1. - С. 131-143.

3. Асланова Д.Т. Личностная и этническая идентичность как предмет исследования в современнойпсихологии» / Д. Т. Асланова // Вестник Ставропольского государственного университета. - № 53. - 2007. - С. 92-96.

4. Борисюк А. С. До проблеми професійної ідентичності майбутнього фахівця / А. С. Борисюк // Практична психологія та соціальна робота. - 2007. №9. - С. 63-68.

5. Гунгер Н. Н. Психологические средства становлення идентичности личности в период нормативного кризиса взрослости : автореферат дис. ... кандидата психологических наук : 19.00.01 / Гунгер Наталья Николаевна. Новосиб. гос. пед. ун-т. - Новосибирск, 2007. - 24 с.

6. Знаменская С. В. Педагогические условия формирования коммуникативной культуры студентов в процессе профессиональной подготовки в вузе : дисс. ... канд. пед. наук : 13.00 .06 / Стояна Васильевна Знаменская. - Ставропольский гос. ун-т, 2004. - 169 с.

7. Козляковський П. А. Загальна психологія: Навчальний посібник: В 2 т. 2-ге вид., доп. і перобл. - Т. II. / П. А. Козляковський. - Миколаїв: вид-во 
МДГУ ім. П. Могили, 2004. - 240 с.

8. Корнаухова Т.А. Формирование нравственно-профкссиональных ценностей у будущего медицинского работника в процессе обучения в колледже ... дис. канд. пед. наук / Т. А. Корнаухова. - Елецкий государственный университет им. И.А. Бунина, 2015. - 222 с.

9. Леонтьев Д. А. Ценность как междисциплинарное понятие: опыт многомерной реконструкции / Д.А.Леонтьев // Вопросы философии. - 1996. №4. - C. 22-24.

10. Методика «Диагностирования уровня эмпатии И. М. Юсупова» общительности [Электронный ресурс]. - Режим доступа : http://docpsy.ru/testy/diagnostika-motivatsii/5058-metodika-diagnostika-urovnyaempatii-i-m-yusupova.html

11. Психология адаптации личности / А. А. Реан, А. Р. Кудашев, А. А. Баранов. - СПб. : Прайм - ЕВРОЗНАК, 2008. - 479 с.

12. Русина С. А. Кризис идентичности студентов в период обучения в вузе С. А. Русина // Педагогическое мастерство и современные педагогические технологи: материалы Междунар. науч.-практ. конф. (Чебоксары, 23 июля 2017 г.). - Чебоксары: ЦНС «Интерактив плюс», 2017. - С. 44-46.

13. Ряховский В. Тест оценки уровня общительности [Электронный pecypc] / В. Ряховский. - Режим доступа : azps.ru/tests/tests_communicativ.htm

14. Фетискин Н. П., Козлов В. В., Мануйлов Г. М. Социальнопсихологическая диагностика развития личности и малых групп / Н. П Фетискин, В. В. Козлов, Г. М. Мануйлов. - М.. : Институт Психотерапии, 2002. $-490 \mathrm{c}$.

The diagnostics of the formation of the professional-personal identity of future nursing specialists in the context of analyzing the levels of formation of the main components of the professional-personal identity of future medical specialists with medical education of the first and second year of study are considered and characterized in the article.

It was substantiated with the help of which the appropriate methods were used to assess the state of formation of the professional-personal identity of future nursing specialists at the stage of the pedagogical experiment. Students mastered the medical college skills of professional-personal self-diagnosis through the prism of self-observation, self-examination, reflection, self-knowledge skills formation.

Key words: diagnostic stage, diagnosis, methods, state of formation, professional personality identity, future specialists in nursing, medical college. 